\title{
Place-based Transformation Policies for Decarbonization. The Art of Timing
}

\author{
Ruediger Wink*
}

\begin{abstract}
With the Covid-19 pandemic causing huge economic and social damages in European regions and revealing necessary transformations to cope with secular distortions in many markets, the European Recovery Plan with its funding instruments create a window of opportunity to stimulate transformative changes particularly in lagging European regions. The paper looks at necessary preconditions for transformative changes on a regional level to create a transformative environment for European firms. Specific challenges in former coal regions are addressed to emphasize the need for place-based transformation strategies, which also consider the need to combine short-term stimulations with long-term transformative perseverance.
\end{abstract}

Keywords: Transformation; Path Dependence; Decarbonization; Industrial Policies; Old Industrial Regions; Global Markets

\section{Covid-19 Pandemics and Slow-Burn Disruptions}

As we can currently observe, no country in the world was perfectly prepared to be confronted by challenges like the Covid-19 pandemic crisis. In 2019, the Global Health Security Index ranked countries according to capabilities to cope with global pandemics and deliberate or accidental release of pathogens (Cameron et al., 2019). The overall result emphasized the weakness of preparedness in almost all countries of the world with at least the best levels of preparedness found in the United States and United Kingdom. The results for European countries were quite diverse with only few countries at top positions. Experiences in spring 2020, however, revealed lacking capacities particularly in the United Kingdom and United States, while European countries like Italy, Spain or France - although very badly affected - were able to at least contain the further spread of the virus.

The enormous economic costs caused by the pandemic in many EU member countries in a very short-term connected with uncertainties about mid-term consequences (OECD, 2020) finally led to an agreement on the EU level to build new structures of common budgetary efforts with new instruments for the European

* Professor of Economics, Leipzig University of Applied Sciences HTWK (ruediger.wink@ htwk-leipzig.de).

Edited by: Niccolò Cusano University

ISSN: $1593-0319$

Wink, R. (2021). Place-based Transformation Policies for Decarbonization. The Art of Timing. Symphonya. Emerging Issues in Management (symphonya.unicusano.it), (1), 100-110.

https://dx.doi.org/10.4468/2021.1.10wink 
Union to directly finance parts of its budgets with debts. At the core of these agreements, a recovery plan for Europe shall boost a change of economic structures not only to cope with the short-term and immediate Covid-19 crisis but also to address deep and long-term structural challenges in the European economies (European Commission, 2020a and 2020b).

The Covid-19 crisis just formed the topping to several secular challenges for European companies requiring immediate transformative strategies like:

- continuously low levels of productivity growth in European economies with obvious problems in maintaining global market competitiveness in future digital and other promising future technology markets despite strengths in basic research (Roeger et al., 2009);

- growing disparities particularly between regions with different characteristics (metropolitan urban vs rural peripheral; Giannakis; Bruggeman, 2020) but also between member countries with different trade patterns (current account surplus vs. deficit countries; Hierro et al., 2018);

- deficits in coping demographic changes and building inclusive qualification strategies to overcome scarcity in many highly-qualified labor market segments (European Commission, 2020c);

- climate change and other major environmental challenges (European Commission, 2020d).

The initiatives by European Commission and several European governments and parliament groups to introduce a recovery plan with new financial instruments and budgetary approaches illustrate "a window of opportunity" (Kingdon, 1995) created by the immediateness and intensity of the Covid-19 pandemic. This short-term window will have to be used not only to stimulate short-term demand and reduce social damages of the health and economic crisis but also to pave the way for a midterm transformation to address the secular challenges.

Although the experiences with Covid-19 are unprecedented in terms of economic and societal challenges, it might make sense to look at the last time a huge amount of funding was mobilized to facilitate transformative changes in European economies. The overview to experiences of economic transformation after the fall of the "iron curtain" in East Germany will illustrate the main challenge this paper looks at: How to overcome barriers to transformative changes particularly in nonmetropolitan old-industrial regions and how to avoid the disappointments during transformative pathways.

\section{Transformation Experiences in the Past}

The transformation shock at the beginning of the 1990s did not only include the necessary integration of Central and East European economies in Western markets but - as currently - further secular challenges occurred for managers and politicians, as globalization took off, capital markets were deregulated and technological changes with the emerging of the Internet were difficult to anticipate. In East Germany, the window of opportunities to develop new institutional structures was extremely short, as the open borders to the economically stronger West Germany attracted particularly highly qualified and more entrepreneurial workforce to migrate to West German 
regions, while they were missed in the process of economic modernization in East Germany (Hunt, 2000). As a consequence, fast unification and the transformation towards the political, economic and social role model of West Germany were recognized as the only option. Helmut Kohl, then chancellor of the unified German government, created the slogan of upcoming "blossoming landscapes" in East Germany in less than a decade. Huge public infrastructure programs, subsidies for private investments, privatization programs and social transfers should lead to necessary production factor growth, which should then lead to steady economic growth and the convergence towards West German economic indicators (Brenke, 2014). In 2019, however, after nearly thirty years of transforming the East German economy, the East German GDP per capita (without Berlin) still only reached $73 \%$ of West Germany, and unemployment rates were still higher (BMWi, 2020). Convergence almost stagnated during the last fifteen years. Economic structures in East Germany dramatically changed during the early 1990s, as de-industrialization set in but only few former industrial workers found new jobs in modern capitalintensive industrial production sites and the service industry.

Today, few East German economic lighthouses and growing attractive urban areas like Leipzig, Dresden, Jena or Potsdam illustrate the potential of successful transformation processes. Even in these successful regions with leading research facilities, highly qualified workforce and service industries, the lack of big firms' headquarter services and private $\mathrm{R} \& \mathrm{D}$ as well as limitations to institutional thickness and cross-industry collaborations are still recognized as barriers to further economic success. Table 1 illustrates the shortcomings of the transformation process in nonmetropolitan parts in East Germany. These regions lost most of their productive workforce and only attracted few "satellite" manufacturing units to be integrated in international value chains. Institutions were not developed according to the needs of transformation processes, and the remaining and new industries in the regions missed the necessary scale and linkages to form new competitive structures.

Table 1: Experiences from Economic Transition in East German Non-Metropolitan Regions

\begin{tabular}{|l|l|l|}
\hline & Initial challenge & Impact on non-metropolitan regions \\
\hline Individual level & $\begin{array}{l}\text { Huge loss of industrial } \\
\text { employment in short-term; no } \\
\text { experiences with market forces }\end{array}$ & $\begin{array}{l}\text { Emigration of entrepreneurial people; } \\
\text { lack of entrepreneurship and focus on } \\
\text { traditions }\end{array}$ \\
\hline Institutions & $\begin{array}{l}\text { Transfer of institutions from } \\
\text { West Germany and EU; limited } \\
\text { participation of East Germans }\end{array}$ & $\begin{array}{l}\text { Institutions fitting to experiences and } \\
\text { needs in West German regions, but } \\
\text { hardly to East German challenges }\end{array}$ \\
\hline Structure & $\begin{array}{l}\text { Decline of traditional resource- } \\
\text { intensive industries }\end{array}$ & $\begin{array}{l}\text { No emergence of new structures but } \\
\text { focus on few capital-intensive } \\
\text { investments }\end{array}$ \\
\hline
\end{tabular}

Neighboring Central and East European countries like Poland, Czech Republic, Slovakia and Hungary faced similar challenges after the fall of the "iron curtain" without a similar access to public capital transfers as in Germany. Acceding the European Union in 2004 further boosted private investments from multinational companies. Nowadays, many industrial production sites are successfully integrated into international value chains, economic indicators in metropolitan urbanized areas reach levels comparable to areas in incumbent EU member countries, and - similar 
to East Germany - many regions outside the urbanized areas lost touch to modern economic structures (European Commission, 2017; Iammarino et al., 2019).

What do these experiences tell us for the transformation tasks we are facing nowadays? Three aspects seem to be important in this context:

1. Successful transformation takes time and is a task for at least one generation. Therefore, perseverance is a crucial factor, and this means particularly to avoid negative reactions in the meantime via exit (migration to other regions) or vote (to return to "old" structures). Realistic communication and the integration of positive interim milestones should support the perseverance.

2. The content of positive framing of transformation differs among regions and individuals. Accordingly, transformation strategies have to be sufficiently open for a diversity of regional and individual characteristics. One overall approach like the market-dominant strategy in Central and East Europe could only reach parts of the affected societies.

3. Transformation needs a well-balanced combination of openness, creativity, change and adventures on the one side and stability, routines and protection on the other side. A too strong focus on protection risks to lose the momentum for change, but a too strong focus on change risks to lose the momentum for the whole strategy (Brondoni, 2020a).

\section{Disruptive Transformations and Path Dependence}

The experiences reveal a dilemma between the need for short-term acceptance and support of change while aiming at mid-term and severe structural changes with risks of business failure and unemployment (Cantoni et al., 2019). So far, however, the short-term perspectives in European regions focused on the avoidance of risks. New technological possibilities coming from digitalization, artificial intelligence, personalized medicine therapies; hydrogen, energy storage and many more will dramatically change business models, daily routines and social communities in the next years. The European economies, however, were only rarely involved in the market implementation of disruptive business models. European governments, firms and citizens painfully experienced the dependence on US platforms during the Covid-19 crisis regardless whether tracing apps, video conferencing, online payments, shopping or streaming became the dominant topics. Similarly, transitions towards renewable energies revealed the dominant role of solar modules and storage battery technologies from Asia. Innovations in Europe were mainly driven by incremental changes and capabilities of firms to combine high technologies and innovative services with more traditional industries (Brondoni, 2020b).

These deficits of disruptive breakthroughs by firms in Europe are often connected with arguments of path dependences and lock-in constellations. The traditional argumentation refers to path-dependent processes along self-reinforcing powers, as big multinational firms in incumbent sectors dominate regional industrial clusters and innovation networks and therefore contribute to cognitive and functional blockades, which neglect the potential for disruptive change and lead to lock-ins without perspectives for transition (see on the debate David, 1985; Hassink, 2009; Martin, 2010). The opposite of these path-dependent processes are path creations, which are often based on charismatic entrepreneurs and narratives (Garud et al., 
2010). Authors like Ron Martin, Michaela Trippl, Robert Hassink or Arne Isaksen showed that reality is a lot more diverse with different forms of changes along pathways like path extension, importation, modernization or upgrading (Hassink et al., 2019; Martin, 2010). The transforming potential of regional pathways usually depends on territorial characteristics of individuals, institutions and structures. Therefore, any transformation strategy has to address these regional specificities.

\section{Regional Transformation and the Individual}

Individual attitudes towards transformation are determined by a variety of factors. Studies on macro-psychological traits and their distribution among regions reveal a strong explanatory power to distinguish between regions with relatively high or low rates of entrepreneurship, high or low shares of job changes, resilience to economic crises, structural changes or economic growth. Specific psychological hindrances to change are observed in former coal regions, as the combination of high job security, additional social benefits, relatively strong social reputation and strict hierarchies, structures and process organization had a strong influence on mentalities (Obschonka et al., 2018). Any changes to these constellations are recognized as threats and have to be rejected. In contrast, regions with a strong reputation for supportive environments for start-ups, freelancers and innovation communities will attract immigration of like-minded individuals, as physical proximity to like-minded communities is still observed as important asset even in sectors with virtual businesses. Consequentially, any transformation strategy will have to find a suitable way to address the messages to actors within the region without causing fears, rejection or ignorance.

The proposals of multinational firms in the digital age coping with unemployment and insolvency during the transformation, a permanent unconditional basic income is often a seemingly attractive way to compensate those who might be threatened to lose their jobs due to automation and/or unable or unwilling to change to the requirements of digitalized markets (Yang, 2018; Straubhaar, 2018). The supporters of this approach refer to it as a "win-win"- constellation, as resistance against disruptions might be reduced and people would not have to fear social and economic damages. Apart from the debates on any potential to finance such an approach and the need for human resources in future markets, this instrument would not fit in any strategy of transformation. New approaches of payment schemes, social security systems and payments for family, care and community work should be part of transformation strategies and should be used to encourage and empower people to participate within the transformation processes. Studies in different European countries on resilience strategies of private households during and after the global financial crisis revealed a strong creative and collaborative potential, but the precondition of any successful coping or adaptation strategy was the existence of stabilizing routines and structures (Promberger, 2017). This observation emphasizes the importance of stabilizing and empowering strategies, which can also help to overcome negative mentalities towards changes.

Any regional transformation process needs agency, i.e. human intervention to institutional routines and structures as well as creative ideas for new business models and community practices. The concept of "trinity of change agency" postulates that 
regional transformation processes need different forms of agency: innovative entrepreneurs recombining knowledge in novel and creative ways, institutional entrepreneurs stimulating deliberately institutional adjustment processes and placebased entrepreneurs being able to connect hitherto unconnected regional actors to form new critical masses for the emergence of regional networks and clusters. (Grillitsch \& Sotarauta, 2020). Again, agents available and needed along the pathways differ among the regions, and transformation strategies need to give way to a variety of constellations, which help to mobilize individual potentials.

\section{Regional Transformation and Institutions}

Quality of governments and trust in institutions play a major role in explaining economic success and capabilities to change of regions in Europe, as several empirical studies showed (Di Cataldo; Rodriguez-Pose, 2015). The change of institutions requires the overcoming of several barriers, as any new institutional rule attacks the stability of expectations about the impact of institutions and changes existing power structures within the regions. Authors from political sciences introduced several modes of institutional changes to describe the variety of options to overcome the barriers to change (Streeck; Thelen, 2005; Mahoney; Thelen, 2010; see also Evenhuis, 2016). Among those modes are:

- "layering", i.e. the addition of new arrangements to an existing institutional framework;

- "conversion", i.e. the redeployment of existing arrangements for new purposes;

- "drift", i.e. the gradual, but considerable loss of relevance of existing arrangements (without their cancellation);

- "displacement", i.e. increasing relevance of arrangements, which may cause other arrangements to be supplanted;

- "dismantling", i.e. disappearance of arrangements;

- "recombination", i.e. new combinations of existing arrangements;

- "churning", i.e. repeated restructuring of existing institutions (mainly as reaction to external forces).

The variety of these modes forms a suitable basis to understand how regional actors, particularly the change agents, might be able to find regionally specific ways to change institutions according to the needs of transforming economies and communities. On a European level, the common vision for this transformation targets for decarbonization, digitalisation, mutual solidarity, social inclusion - has to be formulated, while different institutional pathways within the regions offer specific modes how firms, individuals and civil communities develop their speed, ideas and capabilities to transform structures.

\section{Regional Transformation and Economic Structures}

The debates on path-dependent processes usually refer heavily to structural lock-in constellations typically found in old-industrial regions or in regions with strong focus on exploiting specific natural resources (see Grabher, 1993, on the basic paper to 
introduce this discussion). Here, the irreversibility of investments in technologies, qualifications, knowledge, community codes and machines make it particularly difficult to change towards new cleaner, technological advanced and service-oriented structures, including new urbanized industrial production structures as reaction to deglobalization of supply chains. Of course, it is possible to initiate the emergence of new structures by placing new public basic research institutes and universities, subsidizing private investments in new technologies, offering new venture capital schemes and entrepreneurship programs (Cappellin, 2011). These activities, however, usually depend on external capital, immigration of highly qualified workforce and entrepreneurs and younger and more flexible workforce, while perspectives for older and specialized workers remain gloomy, as access to new high technology and high-productivity might be limited even after qualification efforts.

Here again, experiences in East Germany and Central and Eastern European countries illustrate the risk of losing a generation of workforce by being left without positive professional perspectives and social reputation. Therefore, transition strategies, which combine necessary leapfrog-programs with realistic job perspectives along skill-relatedness from incumbent sectors, will be important elements of any successful recovery plan (see Wink et al., 2017). As a result, structural adjustment pathways will look different in the regions according to their geographical location, cultural and social experiences, historical influences, qualifications, entrepreneurial spirits or firm structure but this diversity will imply a huge potential for Europe to come up with unique patterns of decarbonized, productive and inclusive communities. Table 2 shows a summary of the challenges any regional transformation has to overcome and preconditions on the level of the individuals, institutions and structures to overcome the barriers to change the regional pathways. In the last section, we will look at the strategies in Germany to facilitate the transition towards decarbonization in future former coal regions after successful phasing-out the lignite coal production.

Table 2: Challenges for Regional Transformations and Preconditions for Change

\begin{tabular}{|l|l|l|}
\hline & Challenges & Preconditions \\
\hline Individual level & $\begin{array}{l}\text { Risk-averse mindsets, lack of } \\
\text { entrepreneurship and young firms }\end{array}$ & $\begin{array}{l}\text { Change agents: innovative, institutional } \\
\text { and place-based entrepreneurs }\end{array}$ \\
\hline Institutions & $\begin{array}{l}\text { Institutions with focus on } \\
\text { traditional industries, lack of } \\
\text { flexibility and excess bureaucracy }\end{array}$ & $\begin{array}{l}\text { Modes of institutional changes and } \\
\text { emergence of institutionalized learning } \\
\text { processes }\end{array}$ \\
\hline Structure & $\begin{array}{l}\text { Specialization on resource- } \\
\text { intensive production, specialized } \\
\text { skill structure and infrastructure }\end{array}$ & $\begin{array}{l}\text { Emergence of new structures based on } \\
\text { related and unrelated variety; attraction } \\
\text { of new production factors }\end{array}$ \\
\hline
\end{tabular}

\section{Place-Based Transformation Strategies in German Coal Regions}

One major initiative of the new European Commission refers to the implementation of a "green deal" with the objective to "transform the EU's economy for a sustainable future" (European Commission, 2020d; Salvioni \& Brondoni, 2020). This transformation shall be boosted by an investment plan to spend 1 trillion Euro during the next decade. Besides other activities to reduce the pressure on scarce environmental resources, decarbonization - achieving climate neutrality by 2050 and particularly rapid phasing-out of coal and decarbonizing of gas are among the 
Commission's major priorities. Germany being still the world's biggest user of lignite coal in 2015 and covering $37 \%$ of its energy needs for electricity in 2017 by coal power plants (nearly half of these based on lignite coal) decided to phase-out its lignite coal production until 2038. Other important producers of fossil fuels like e.g. Poland will face similar challenges, when the vision of the European "green deal" shall become reality. While the time schedule until 2038 seems to be a long time to organize the transformation process, challenges for affected regions are still enormous (DIW et al., 2018): lignite coal production, particularly in East Germany, is spatially concentrated in less diversified and more rural areas. The share of lignite coal production in total value added of single districts was still up to nearly $44 \%$ in 2015 (Spree-Neiße-Kreis) despite a decline of total lignite coal production in the two East German lignite coal areas. Lusatia accounted by two third (employment by $88 \%$ ) between 1990 and 2017 and Central Germany by 77\% (employment by 96\%) between 1990 and 2017. This decline until 2017, however, was not accompanied by a transformation towards new sectors, markets and qualifications but primarily realized by emigration of younger people and retirement schemes for older workers. Therefore, even the declining lignite sector still belongs to the dominant economic activities in the affected East German regions.

The availability of change agents differs among the German lignite coal regions (DIW et al., 2018). In West Germany, the biggest lignite coal area profits from geographical proximity to important metropolitan areas like Cologne and its neighboring cities or the trilateral science region with cities like Aachen, Eindhoven and Liège. As a consequence, change agents from the surrounding areas can support the transformation process in the coal region and increase the probability to compensate for the job loss in the coal sector. In this case, place-based entrepreneurs are particularly important, as they might help to connect actors from hitherto unconnected areas and sectors and mobilize the spillover potential towards the former coal region. Similarly, the second lignite coal region in West Germany could be supported from a neighboring automotive region like Wolfsburg (Volkswagen) or could be developed by their own resources like the regional university, research organizations or regional firms.

In the two East German regions, however, less promising preconditions are currently available. The Central German lignite coal area might profit from its geographical proximity to Leipzig but administrative barriers (regional borders between Saxony, Saxony-Anhalt and Thuringia), lack of digital infrastructures, mobility systems and cultural barriers between Leipzig and non-urbanized surrounding areas limit the connectivity (Wink et al., 2016). Therefore, institutional change agents will be needed to overcome the existing administrative barriers and limitations in interregional collaboration. Furthermore, collaboration between the urbanized area of Leipzig and more rural areas in the lignite coal region require time to find new codes of communication and trust between communities with different cultural backgrounds and mentalities. Therefore, connecting projects (mobility systems, joint cultural and sport events or natural conservation areas) are planned to reveal mutual benefits for all affected groups.

The most challenging context will be addressed in the second East German region Lusatia (Markward et al., 2016). Here, government programs shall boost a leapfrog process towards a region of high-tech excellence in artificial intelligence and digitalization (DIW et al., 2018) although almost no factors are currently present in 
this more rural and peripheral region. Therefore, mobilization of regional change agents - in particular innovative and place-based entrepreneurs - will be important for the acceptance of transformation in the region by developing interim transitions along related sectors in small crafting businesses, renewable energy production and energy-intensive businesses based on "green hydrogen" and renewable energies. In Table 3 the strategies for the transformation in East German future former coal regions are described on the level of individuals, institutions and structure. Table 2 and Table 3 show the risks within these strategies. On the individual level, the change agents shall be attracted from outside the regions without necessary linkages to current territorial identities in the regions. On the level of institutions, incumbent institutions shall not be replaced but amended by new institutional layers, which might need time to be accepted and implemented in the regions; and on the level of structures, in particular the targeted unrelated variety in Lusatia might lead to island of high technology without any linkage to current regional industries and labor markets. These discrepancies might cause new disappointments and the failure to create the place-based grounding to emerge into new regional employment and value chains.

Table 3: Political Strategies to Overcome Barriers to Transformation in East German Future Former Coal Regions

\begin{tabular}{|c|c|c|}
\hline & Challenges & $\begin{array}{l}\text { Political strategies for East German } \\
\text { future former coal regions }\end{array}$ \\
\hline Individual level & $\begin{array}{l}\text { Risk-averse mindsets, lack of } \\
\text { entrepreneurship and young } \\
\text { firms }\end{array}$ & $\begin{array}{l}\text { Invitations to people with entrepreneurial } \\
\text { mindsets from neighboring cities; } \\
\text { development of new image and identity }\end{array}$ \\
\hline Institutions & $\begin{array}{l}\text { Institutions with focus on } \\
\text { traditional industries, lack of } \\
\text { flexibility and excess } \\
\text { bureaucracy }\end{array}$ & $\begin{array}{l}\text { Incentives to create new institutions on a } \\
\text { community level, additional institutional } \\
\text { layers with incumbent and new agents }\end{array}$ \\
\hline Structure & $\begin{array}{l}\text { Specialization on resource- } \\
\text { intensive production, } \\
\text { specialized skill structure and } \\
\text { infrastructure }\end{array}$ & $\begin{array}{l}\text { Central Germany: related variety to } \\
\text { chemical, energy and food industry } \\
\text { Lusatia: unrelated variety with artificial } \\
\text { intelligence and big data application }\end{array}$ \\
\hline
\end{tabular}

Despite all the negative impact of Covid-19, the window of opportunity created by the European recovery plan offers a unique opportunity to kickstart the transformation. The experiences in Germany, however, shall help to focus more on mid-term place-based transformation perspectives, which are connected to shortterm capabilities and attitudes on the individual level, institutional experiments within existing frameworks and structural adjustments along skill- and technologyrelatedness to maintain acceptance in the regions.

\section{Bibliography}

BMWi - German Ministry for Economic Affairs and Energy (2020). Jahresbericht der Bundesregierung zum Stand der Deutschen Einheit 2020. Berlin: BMWi.

Brenke, K. (2014). Eastern Germany Still Playing Economic Catch-up. DIW Economic Bulletin, 11, 6-23.

Brondoni, S. M. (2020a). US, China, Japan, SK \& EU: Industrial Strategies and Global Firm Challenges. Symphonya. Emerging Issues in Management (symphonya.unicusano.it), (2), 89-103. 
http://dx.doi.org/10.4468/2020.2.10brondoni

Brondoni, S.M. (2020b). Competitive Circular Economy Management. The Mitsubishi Corporation Case. Symphonya. Emerging Issues in Management (symphonya.unicusano.it), (1), 10-25.

http://dx.doi.org/10.4468/2020.1.02brondoni

Cameron, E. E., Nuzzo, J. B., \& Bell, J. A. (2019). Global Health Security Index. Building Collective Action and Accountability. Washington, DC: Nuclear Threat Initiative and Johns Hopkins University.

Cantoni, F., Graziano, P., Maiocchi, F., \& Rizzi, P. (2019). A Territorial and Organizational Approach to Resilience. Symphonya. Emerging Issues in Management (symphonya.unicusano.it), (2), 109-118. http://dx.doi.org/10.4468/2019.2.10cantoni.graziano.maiocchi.rizzi

Cappellin, R. (2011). Growth, Consumption and Knowledge Cities. Symphonya. Emerging Issues in Management (symphonya.unimib.it), (2), 6-22.

http://dx.doi.org/10.4468/2011.2.02cappellin

David, P. A. (1985). Clio and the Economics of QWERTY. American Economic Review, 75(2), 332-337.

Di Cataldo, M.; Rodriguez-Pose, A. (2017). What Drives Employment Growth and Social Inclusion in the Regions of the European Union? Regional Studies, 51(12), 1840-1859.

http://dx.doi.org/10.1080/00343404.2016.1255320

DIW - German Institute for Economic Research; Wuppertal Institut; eco logic (2018). Die Beendigung der energetischen Nutzung von Kohle in Deutschland. Ein Überblick über Zusammenhänge, Herausforderungen und Lösungsoptionen. Berlin: DIW.

European Commission (2017). My Region, My Europe, Our Future. $7^{\text {th }}$ Report on Economic, Social and Territorial Cohesion. Brussels: European Commission.

European Commission (2020a). Recovery Plan for Europe.

https://ec.europa.eu/info/live-work-travel-eu/health/coronavirus-response/recovery-planeurope en\#financing-the-recovery-plan-for-europe.

European Commission (2020b). NextGenerationEU: Commission Presents $€ 675$ Billion Recovery and Resilience Facility in 2021 Annual Sustainable Growth Strategy. Press Release.

https://ec.europa.eu/commission/presscorner/detail/en/ip_20_1658

European Commission (2020c). Report from the Commission to the European Parliament, the Council, the European Economic and Social Committee and the Committee of the Regions on the Impact of Demographic Change. Brussels. COM (2020) 241 final 17/06/2020.

European Commission (2020d). Sustainable Europe Investment Plan. European Green Deal Investment Plan. Communication from the European Commission to the European Parliament, the Council, the European Economic and Social Committee and the Committee of the Regions. Brussels.

Evenhuis, E. (2016). The Political Economy of Adaptation and Resilience in Old Industrial Regions: A Comparative Study of South Saarland and Teesside. Dissertation. Newcastle: CURDS.

Garud, R., Kumaraswamy, A., \& Karnoe, P. (2010). Path Dependence or Path Creation? Journal of Management Studies, 47(4), 760-774.

Giannakis, E., \& Bruggeman, A. (2020). Regional Disparities in Economic Resilience in the European Union across the Urban-Rural Divide. Regional Studies, 54(9), 1200-1213.

http://dx.doi.org/10.1080/00343404.2019.1698720

Grabher, G. (1993). The Weakness of Strong Ties - The Lock-in of Regional Development in the Ruhr Area, in Grabher, G. (ed.), The Embedded Firm. London \& New York: Routledge.

Grillitsch, M., \& Sotarauta, M. (2020). Trinity of Change Agency, Regional Development Paths and Opportunity Spaces. Progress in Human Geography, 44(4), 704-723.

http://dx.doi.org/10.1177/0309132519853870

Hassink, R. (2009). Locked in Decline? On the Role of Regional Lock-ins in Old Industrial Areas, in Boschma, R., \& Martin, R. (eds), Handbook of Evolutionary Economic Geography. Cheltenham: Edward Elgar. 
Hassink, R., Isaksen, A., \& Trippl, M. (2019). Towards a Comprehensive Understanding of New Regional Industrial Path Development. Regional Studies, 53(11), 1636-1645.

http://dx.doi.org/10.1080/00343404.2019.1566704

Hierro, L. A., Atienza, P., \& Hailer, A. M. (2018). Internal Trade Imbalances and Economic Growth in the Eurozone. Sevilla: Universidad de Sevilla.

Hunt, J. (2000). Why do People Still Live in East Germany? IZA Discussion Paper No. 123. Bonn: Institute for the Study of Labour.

Iammarino, S., Rodriguez-Pose, A., \& Storper, M. (2019). Regional Inequality in Europe: Evidence, Theory and Policy Implications. Journal of Economic Geography, 19(2), 273-298.

Kingdon, J.W. (1995). Agendas, Alternatives and Public Policies. London: Longman.

Mahoney, J., \& Thelen, K. (2010). A Theory of Gradual Institutional Change, in Mahoney, J., \& Thelen, K. (eds.), Explaining Institutional Change: Ambiguity, Agency, and Power. Cambridge: Cambridge University Press.

Markwardt, G., Mißler-Behr, M., Schuster, H., Zundel, S., \& Hedderoth, J. (2016). Strukturwandel in der Lausitz. Wissenschaftliche Auswertung der Potentialanalysen der Wirtschaft der Lausitz ab 2010. Cottbus: BTU Cottbus-Senftenberg.

Martin, R. (2010). Rethinking Regional Path Dependence: Beyond Lock-in to Evolution. Economic Geography, 86(1), 1-27.

Neuhäusler, P.; Rothengatter, O. (2020). Patent Applications - Structures, Trends and Recent Developments 2019. Studien zum deutschen Innovationssystem. Berlin: Commission of Experts for Research and Innovation.

Obschonka, M., Stuetzer, M., Rentfrow, P. J., Shaw-Taylor, L., Satchell, M., Silbereisen, R. K., Potter, J., \& Gosling, S. D. (2018). In the Shadow of Coal. How Large-Scale Industries Contributed to Present-Day Regional Differences in Personality and Well-being. Journal of Personality and Social Psychology, 115(5), 903-927.

http://dx.doi.org/10.1037/pspp0000175

OECD - Organisation of Economic Cooperation and Development (2020). Building Confidence and an Uncertain Recovery. OECD Economic Outlook Interim Report. Paris: OECD.

Promberger, M. (2017). Resilience Among Vulnerable Households in Europe. Questions, Concept, Findings and Implications. IAB Discussion Paper 12/17. Institute for Employment Research. Nuremberg.

Roeger, W., Varga, J., \& in't Veld, J. (2009). How to Close the Productivity Gap Between the US and Europe. A Quantitative Assessment Using a Semi-Endogenous Growth Model. Brussels: European Commission - Directorate General Financial Affairs.

Salvioni, D. M., \& Brondoni, S. M. (2020). Ouverture de 'Circular Economy \& New Business Models’. Symphonya. Emerging Issues in Management (symphonya.unicusano.it), (1), 1-9.

http://dx.doi.org/10.4468/2020.1.01ouverture

Strambach, S., \& Halkier, H. (2013). Reconceptualizing Change. Path Dependency, Path Plasticity and Knowledge Combination. Zeitschrift für Wirtschaftsgeografie, 57(1-2). 1-14.

Straubhaar, T. (2018). Universal Basic Income - New Answers to New Questions for the German Welfare State of the $21^{\text {st }}$ Century. Cesifo Forum, 19(3), 3-9.

Streeck, W., \& Thelen, K. (2005). Institutional Changes in Advanced Political Economies, in Streeck, W., \& Thelen, K. (eds.), Beyond Continuity: Institutional Change in Advanced Political Economies. Oxford. Oxford University Press.

Wink, R., Kirchner, L., Koch, F., \& Speda, D. (2016). Wirtschaftliche Resilienz in deutschsprachigen Regionen. Wiesbaden: Springer-Gabler.

Wink, R., Kirchner, L., Koch, F., \& Speda, D. (2017). Agency and Forms of Path Development Along Transformation Processes in German Cities. Cambridge Journal of Regions, Economy and Society, 10(3), 471-490.

Yang, A. (2018). The War on Normal People: The Truth About America's Disappearing Jobs and Why Universal Basic Income Is Our Future. New York: Hachette Books. 